DOI https://doi.org/10.30525/978-9934-26-073-5-1-27

\title{
ПОСТМОДЕРНА ЕСТЕТИКА ПОВІСТІ ІРЕНИ КАРПИ «50 ХВИЛИН ТРАВИ»
}

\author{
Веретюк T. B. \\ кандидат філологіних наук, \\ доцент кафедри украӥнської літератури та журналістики \\ імені професора Леоніда Ушкалова \\ Харківського наиіонального педагогічного університету \\ імені Г. С. Сковороди \\ м. Харків, Україна
}

Українській постмодерній літературі притаманні такі риси: «принцип гри; злиття трагедії й фарсу, іронії й самоіронії, пародії й самопародії; зміщення акцентів з рівня високого звучання на нижчий; перекодування мотивів, висловлювань, сакральних відчуттів і почуттів; тривіальна й вульгарна мова; пульсація різних стильових тенденцій; епатажність; зміна функцій автора та героя; культ незалежної особистості; потяг до архаїки, міфу; прагнення поєднати істини різних культур, релігій, філософій; інтертекстуальність» [2, с. 438]. Спробуймо проаналізувати повість Ірени Карпи «50 хвилин трави» крізь призму постмодерної естетики.

Повість «50 хвилин трави» Ірени Карпи зацікавлює та епатує читача вже самою назвою, яка вказує на постмодерний характер твору. Прикметно, що цей художній текст не про наркозалежних людей, а про кохання, взаємовідносини між чоловіком і жінкою, моделі їхньої поведінки в сучасному нестабільному світі, хоча сцени наркотичного оп'яніння, безумовно, присутні в повісті.

Головні герої твору (Свка і Даня) мають нестандартні стосунки, вони то вірні одне одному, то змінюють сексуальних партнерів, підвищуючи в такий спосіб свою самооцінку та собівартість. Приміром, Свку авторка зображує закомплексованою дівчиною, яка страждає на часті депресії, схиблена на маніакальних ідеях про власну смерть, намагається сховатися за маскою стерви, прагне підвищити свою самооцінку за рахунок чоловіків: «Це я маю тебе, скурвий сину, це я мала вас всіх, пхала вас у себе, а потім викидала на смітник, одного по одному!» [5, с. 70], або: «...Ти ж кохаєш його [Даню], а розкидаєш себе наліво i направо, роздаючи всяким уродам те, що має належати йому одному!» $[5$, c. 32]. Переїжджаючи з одного міста до іншого, змінюючи коханців, 
дівчина розраховує в такий спосіб «відсіяти» зайве, щоб у результаті віднайти єдине, справжнє кохання.

Прикметним є й авторська інформація про те, що Свка і Даня лузери, невдахи: «Ти запустив у себе невдаху, й одного дня це стерво проросте крізь твої вуха, ніс, горло, дупу буйним пурпуровим цвітом» [5, c. 48], «I'm thoughtless. You're strengthless - я бездумна, ти безсилий» [5, с. 12]. Т. Гундорова зазначає, що «для Свки це стає лейтмотивом історії про кохання, яке може реалізуватися не в цьому житті, а лише після смерті. Свка не може чути дитячий плач, бо він нестерпний, бо «у ньому годі було дошукуватися сенсу. Як і в дітях взагалі. Свка не хотіла мати їх, вона вже наперед ненавиділа все, що могло вилізти з іiі паскудного нутра»»» [4, с. 26].

У повісті спостерігаємо заниження відчуттів, вражень, почуттів, які можуть, нібито, «скомпрометувати» героїню, засвідчити слабкість іiі характеру: «Плювала я на шмаркаті страждання, я ЖИВУ», «позови сумління (майже як позови до туалету)» [5, с. 4]. Т. Гундорова вбачає симптоматику такого стану в генезі хвороби: «й бл блювалося піврічними депресіями i завислими поглядами, туберкульозними висадками i грибковими захворюваннями, жагою параної (я люблю метеликів!) i страхом психозу» [4, с. 26].

Аналізуючи повість І. Карпи «50 хвилин трави», О. Поліщук акцентує увагу на тому, що у своїх творах мисткиня вдається до демонстративної відвертості (опис інтимних стосунків, відкрита розмова про суто особисте), ненормативної лексики, як й О. Забужко у творі «Польові дослідження з українського сексу». Це виявилося зокрема в імітації автобіографічно-щоденникового стилю письма, наслідуванні стилю потоку думки; масці відвертості, винесенні на показ інтимного; темі «совкізму», пов'язаної з темою центру й провінції [8, с. 87].

Особливу функцію у творі відіграє мова. У тексті переважає сленг, обсценна лексика («до сраки нам комфорт», «курва мать», «сам ти дебільна ізотерика»), суржик, міксування різних мов, зокрема англійської, російської, французької та української: («Вся єда палєзна!», «е-левsince-KOІ містерії»). У творі превалює опис еротичних («...він відкушує від гриба і дуже повільно жує, а вона в цей час пестить йому прутня») та наркотичних сцен («Рештки шарової наркоти й туманних галюцинацій приємно погладили Євку через слухавку»).

Слід зазначити, що мозаїчність, колажність та фрагментарність художнього тексту є головними рисами сучасної української літератури. Звернення письменників до фрагментарного наративу можна пояснити тим, що фрагментарність віддзеркалює внутрішні, психологічні та 
емоційні проблеми головних героїв твору, їхнє самовідчуття та самоусвідомлення [3, с. 104]. Для композиції повісті «50 хвилин трави» теж характерна постмодерністська фрагментарність, крім того текст перемежовується листами Свки, їі спогадами про коханців, студентські роки тощо: «Свка читала ті листи в метро. Читала 3 таким страшним обличчям, що люди ледь не вступали їй місця. Але Євка не звалилась на підлогу, людські задки залишились там, де й були - світ косив під константу, вдаючи, що нічого не змінилось» [5, с. 28], «Їй прийшов товстенний лист від коханця з Берліну. Ще один лист від іще одного коханця» $[5$, с. 60$]$.

Поява на сторінках текстів I. Карпи біографічних фактів сприймаються як ще одна спроба втілення естетики постмодернізму. Так, Л. Лавринович зауважує, що «сучасна українська проза переважно $є$ автобіографічною, тобто іiі визначає особа автора» [6, с. 40]. У тексті повісті I. Карпи знаходимо спроби обіграти авторське ім'я, прямі вказівки на біографічні моменти. Приміром, «Моррісону було байдуже, хоч він і народився з Свкою в один день. Шкода, що не того ж року. А от Джона Леннона вбили якраз того ж року. I того ж дня» [5, с. 33]. Варто зауважити, що й американський співак, поет, лідер гурту «The Doors» Дж. Моррісон, і героїня повісті Свка, й І. Карпа народилися в один день 8 грудня, а сама письменниця та героїня іiі твору ще й в один рік із загибеллю Дж. Леннона - у 1980-му, що суттєво зближує Євку й авторку. Таку автобіографічність у повісті можна вважати «своєрідним атрибутом авторської маски, хоча використання прийомів цитати, алюзії, використання стилю «щоденникового письма» нагадують спробу приміряти на себе «чужий літературний одяг»»» [8, с. 88].

Утіленням принципів постмодернізму в повісті також $\epsilon$ рясне використання ремінісценцій (наприклад, «Все закрито. Вісім огорож. Це пекло у Сартра, здається...» [5, с. 37] або: «Що бути ПітерПеном, звісно, добре, але все-таки хочеться хоч колись подорослішати і зробити щось серйозне» [5, с. 68] тощо) та цитатність, яка в тексті твору відтворена переважно іноземною мовою («Die Gesinchtszuge / Потяги твого обличчя - / die Gesinchtszuge / (в сенсі) / поїзди твого обличчя - / Сильно / відрізняються / від іншого / i / brechen-brach. / Gebrochen» (уривки, фрази 3 коміксів) [5, с. 47-48] або: «We sail tonight to Singapore...» (рядок з пісні Тома Вейта) [5, с. 33]).

Не оминула письменниця й мотив подорожування, який популярний у «західно-постмодерністській» літературі, що, на думку Л. Печерських, в українській прозі перетворюється «на «пошук нових орієнтирів, шлях до себе та своєї країни», «осягнення власної екзистенції та екзистенції 
своєї країни»» [7, с. 42]: «Свка завезла Даника у Карпати і там залишила» [5, с. 40], «Свка зібрала рюкзак і поїхала до Києва» [5, с. 41], «Ну, а потім ще пробували поїхати в сусідній обласний центр, потім - до моря і назад, ще пізніше - на ще якусь дискотеку» [5, с. 45], «Вони збирались до Африки» [5, с. 58].

Процес моральної переорієнтації суспільства сприяв появі іронічного світосприймання, визначальним етапом якого можна вважати руйнацію «усталених опозицій. Тенденції витіснення загальновизнаних норм на периферію i, відповідно, актуалізація маргінального створили сприятливі передумови для нівелювання різниці між центром i периферією, естетичним i неестетичним, істинним i помилковим, елітарним i масовим» [1, с. 149]. Іронічність як одна з рис постмодернізму знаходить своє втілення у повісті, тим самим не лише утверджуючи приналежність I. Карпи до постмодерністів, а й удосконалюючи ії індивідуальний стиль. Л. Печерських переконує, що «як відтінок сміху іронія виникає найчастіше в ситуаціях, коли в підтексті сказаного відчувається знущання» [7, с. 44]. Так, у творі І. Карпи знаходимо схожу тенденцію: «Любий, ти не знаєш, коли у сімейства білявчиків закінчується линяння? Нє, звичайно, твоє волосся в салатах мені дуже смакує, окрім того, надзвичайно приємно знаходити твої сліди у себе на одязі...» [5, с. 67].

Отже, у повісті «50 хвилин трави» постмодерна естетика втілена через заниження відчуттів, вражень, почуттів головної героїні; демонстративну відвертість, опис інтимних стосунків; появу в тексті біографічних фактів 3 життя авторки та численних натяків на те, що головна героїня твору і $є$ сама I. Карпа; рясне використання ремінісценцій, цитатність, іронію, інтертекстуальність, мотиви подорожування.

\section{Література:}

1. Акулова Н. Постмодернізм як філософсько-естетичне явище. Вісник Харківського національного університету імені В. Н. Каразіна. Серія «Філологія». Харків, 2007. Випуск 50. С. 146-150.

2. Андрусяк I. Сучасна українська література кінця XX - поч. XXI ст.: [Для ст. шк. віку] / Упорядкув. текстів, передм., підготовка навч.-метод. матеріалів I. Андрусяка. К.: Школа, 2006. 464 с.

3. Герасименко Н. Наші підлітки - жертви Стівена Кінга. Слово і час. 2008. № 4. C. 43-48.

4. Гундорова Т. Симптоматика «хворого тіла». Критика. 2010. № 7-8 (№ 153-154). C. 24-26.

5. Карпа I. Жовта книга [Текст]. Харків: Книжковий Клуб «Клуб Сімейного Дозвілля», 2010. 320 с. 
6. Лавринович Л. Сучасний український постмодернізм напрям?стиль? метод? Слово $і$ час. 2001. № 1. С. 39-46.

7. Печерських Л. Концептуальні дискурси сміхової культури в українській прозі 90-х років ХХ століття (творчість Юрія Андруховича): Монографія. Харків: Майдан, 2008. 160 с.

8. Поліщук О. Автор і персонаж в українській новітній прозі. К.: ПЦ «Фоліант», 2008. 176 с.

DOI https://doi.org/10.30525/978-9934-26-073-5-1-28

\title{
АВТОРСЬКИЙ ТЕКСТ-МІФ ТА МОТИВ «ПОДОРОЖІ У ЧАСІ» ЯК СПОСІБ РЕЦЕПЦІЇ ТРАДИЦІЙНОГО СЮЖЕТНО-ОБРАЗНОГО МАТЕРІАЛУ НА ПРИКЛАДІ ДРАМИ ЛЕСІ ВОЛОШИНОЇ «ЕЛЬЗА. ПРИТЧА ПРО ЛЮБОВ»
}

\author{
Гуцол М. І. \\ кандидат філологічних наук, доцент, \\ дочент кафедри мовознавства \\ Івано-Франківського національного медичного університету \\ м. Івано-Франківськ, Україна
}

Кожна історична епоха відображається через міфологізацію власного минулого та запозичення міфологічних сюжетів та образів з інших культур. Міфологія здавна приваблювала дослідників, а сучасна література, означена як епоха «ендизмім» (за визначенням Джона Барта) презентує цілісну систему апелювання до першоджерел людської цивілізації в пошуках відповіді на «вічні питання» буття. Водночас «альтернативна реальність» міфу відкриває неозорий простір для письменницьких експериментів і творчих рефлексій.

У вітчизняному літературознавстві крізь призму міфокритики розглядали широкий спектр проблем у своїх дослідженнях Дж. Грабович, Олена Бондарєва, Оксана Забужко, Ніла Зборовська, Оксана Когут та інші. Науковці використовують напрацювання як антропологічної гілки (Фрейзер), так і архетипної критики та психоаналітики (Сергій Аверинцев, Мірча Еліаде, Нортроп Фрай), постструктуралістів, семіотиків і деконструктивістів (Ролан Барт, Жак Деррида, Мішель Фуко). Проте сьогодні, на жаль, ще немає досліджень інтерпретації традиційної сюжетно-образної системи міфу в контексті української постмодерної драматургії. 